\title{
Effect of Multiple Taxation on the Performance of Small and Medium Scale Business Enterprises. (A Study of West African Ceremics Ajeokuta, Kogi State)
}

\author{
Adebisi, J.F Ph.D \\ Director- General, Nigerian college of Accountancy, Jos, Nigeria.
}

Gbegi, D.O.

Department of Accounting, Kogi State University, Anyigba, Nigeria. gbegidan@gmail.com.

\section{Doi:10.5901/mjss.2013.v4n6p323}

\section{Abstract}

This study is on the effect of multiple taxation on the performance of small and medium scale enterprises. Over the years, small and medium scale enterprises have been an avenue of job creation and the empowerment of Nigeria's citizen, providing about $50 \%$ of all jobs in Nigeria and also for local capital formation. However, the mortality rate of these small firms is very high. Among the factors responsible for these untimely close-ups are tax related issues, ranging from multiple taxation to enormous tax burdens. The study therefore examines the effect of multiple taxation on SMEs survival. The study involved a survey research design with a population of 91 . The researchers derived their sample size to arrive at 74 and a self administered questionnaire was used to collect data. These data was quantitatively analyzed with simple percentages and tested the research hypothesis with ANOVA. Findings revealed that multiple taxation has negative effect on SMEs' survival and the relationship between SMEs' size and its ability to pay taxes is significant. We therefore recommends that government should come up with a uniform tax policies that will favour the development of SMEs in Nigeria and government should put into consideration the size of SMEs when setting tax policies.

Keywords: Multiple Taxations, SMEs Performance, SMEs Mortality, Economic Growth.

\section{Introduction}

In recent time the world economy has developed tremendously and this has been linked with activities of Small and Medium Scale Enterprises (SMEs), especially in developing countries. A Study carried out by the Federal Office of Statistics shows that in Nigeria, Small and Medium Scale Enterprises make up 97\% of the economy (Ariyo, 2005). Although smaller in size, they are the most important enterprises in the economy due to the fact that when all the individual effects are aggregated, they surpass that of the larger companies. The social and economic advantages of small and medium scale enterprises cannot be overstated. Panitchpakdi (2006) sees SMEs as a source of employment, competition, economic dynamism, and innovation which stimulates the entrepreneurial spirit and the diffusion of skills. Because they enjoy a wider geographical presence than big companies, SMEs also contribute to better income distribution. Over the years, small and medium scale enterprises have been an avenue for job creation and the empowerment of Nigeria's citizens providing about $50 \%$ of all jobs in Nigeria and also for local capital formation. Being highly innovative, they lead to the utilization of our natural resources which in turn translates to increasing the country's wealth through higher productivity. Small and medium scale enterprises have undoubtedly improved the standard of living of so many people especially those in the rural areas (Ariyo, 2005).

However, the mortality rate of these small firms is very high. According to the Small and Medium Scale Enterprises Development Agency of Nigeria (SMEDAN) Nigeria, $80 \%$ of SMEs die before their $5^{\text {th }}$ anniversary. Among the factors responsible for these untimely close-ups are tax related issues, ranging from multiple taxations to enormous tax burdens etc. In many government policies, small and medium scale enterprises are usually viewed and treated in the same light as large corporations. However, their size and nature makes them unique. Therefore, in dealing with small and medium scale enterprises, these unique qualities need to be considered. In levying of taxes for these enterprises in particular, issues that need to be considered are how these tax policies can be designed to bolster the growth of SMEs and the 
most effective ways to administer them. The importance of SMEs as a mechanism of economic growth arid development is often ignored.

They are perceived as minute establishments that have minimal effect on the state of the economy. However, if favorable environment is created for these SMEs to grow through proper regulation, the SMEs sector has the highest propensity to transform our economy. In the same light, taxes are important for the government as they are the major source of funds for government expenditure. Income obtained from taxation of individuals and businesses are used to run governments as well as provide infrastructure such as good roads, water supply, and electricity which are essential for the smooth running of these businesses that are mainly manufacturing companies and as such rely on these commodities to survive.

However, Holban (2007) posited that taxation can contribute to development and to welfare through three sources; It must be able to generate sufficient funds for financing public services and social transfers at a high level of quality, it should offer incentive for more employment and for an efficient and lasting use of natural resources, finally it should be able to reallocate income. But in the case of SMEs, tax must be done in such a way that puts their income and need for survival into consideration. it is expedient that enough profit is allowed them for the purpose of expanding their businesses. The tax policy must be one that will not encourage SMEs to remain in the informal sector or to evade or avoid tax payments. More so, many small firms in Africa, including Nigeria, choose to remain in the informal sector because the perceived benefits outweigh the perceived costs. Firms rarely see their tax contributions at work and the compliance costs are high, thus discouraging compliance. The government is also discouraged from collecting taxes from small firms, because the cost of monitoring and collecting tax from small businesses by revenue authorities, whose resources are usually scarce, sometime outweighs the revenues generated by small businesses (Stem and Barbour 2005).

The focus of this research therefore is to examine the effect of multiple taxations on the performance of (SMEs) and the importance of taxes to the Nigerian economy, to establish the relationship between tax policy and the growth of SMEs in Nigeria and to evaluate the factors that encourage non-compliance with tax obligation by SMEs,

\section{Statement of the Problem}

Although there was a general perception that tax is an important source of fund for development of the economy and provision of social services, the problems faced are in the area of negative relationship between taxes and the business' ability to sustain itself and to expand, SMEs are faced with the problem of high tax rates, multiple taxation, complex tax regulations and lack of proper enlightenment or education about tax related issues. Not minding other challenges that SMEs are facing in other developing countries like Nigeria; inadequate capital, poor technical and managerial skills, environmental effects and the government regulations which is most affecting the operation of SMEs in Nigeria especially this issue of multiple taxation which is a worm eating deeply and the large chunk of revenues generated by these SMEs for their growth and survival. These have led to increase in record of dearth of Small and Medium Scale Enterprise (SMEs).

\section{Objectives of the Study}

The general objective of the study is to examine the effect of multiple taxations on SMEs performance.

(i) To examine the relationship between multiple taxation and SMEs survival.

(ii) To ascertain whether SMEs ability to pay taxes depends on their size

\section{Statement of Hypotheses}

The following research hypotheses were developed in order to properly address the problems of the study. These hypotheses were stated in Null form as follows:

(i) Ho1: There is no significant relationship between multiple taxation and SMEs' survival.

(ii) Ho2: The relationship between SMEs' size and it ability to pay taxes is not significant.

\section{Conceptual Issues}

For some decades now, Nigeria has depended on oil for its major income and foreign exchange. Oil accounts for about 
80 percent of federal government revenues, and 95 percent of foreign exchange earnings. The National Centre for Economic Management and Administration (NCEMA) reports that Nigeria, with a population of about 120 million, is Africa's most populous country and the continent's third largest economy yet it still remains one of the poorest oil producing countries. With a continuously declining per capita income, comparatively unfavorable social indicators, dynamic world economy and the fact that countries are looking into alternative sources of energy it is time to begin to look into alternative sources of income for sustenance in the long run when the demand for oil will dwindle to nothing. Even with the present rates of petroleum products, Nigeria's CDP is below ideal with the SMEs contributing therefore it would not hurt to diversify the economy even before the demand for petroleum products finally diminishes. This means it is time to begin to give more attention to the other sectors of the economy.

This translates into looking at non-oil based sectors in Nigeria such as agriculture, manufacturing, commerce and tourism. These industries are primarily made up of SMEs as such it goes without saying that SMEs are important to the Nigerian economy. The country is blessed with fertile farmlands, vast mineral deposits and a wealth of human resource, making it a very favorable place for small arid medium enterprises. These resources have $p$ laced Nigeria in a prominent position in Africa, For governments, however, large companies are a more attractive, more clear-cut and less complex set than SMEs, In designing public policies, particularly tax policies, governments have usually targeted their strategies to large companies (Holban, 2007). Therefore, there is a need to devise methods to encourage the growth and development of these enterprises so as to ensure that they reach their full potential. Subsequently, a favorable business and regulatory environment needs to be created for them to thrive. Thus, for this study, the focus will be on supporting SMEs growth through tax policy. Most large companies have their roots in small and medium enterprises; they started out as SMEs before expanding. This means that the future large corporations are the SMEs today that should be nurtured to ensure their growth. Furthermore, they are generally perceived to be the seedbed for indigenous entrepreneurship and generate all the many small investments, which would otherwise not have taken place (Aryeetey \& Ahene, 2004).Therefore, Nigeria needs to further the development of its private sector by creating an environment favorable to the growth of SMEs, strengthening the factors that lead to business success, and addressing the problems threatening the existence and advancement of small and medium enterprises (Chu, Kara \& Benzing, 2008) With the dismantling of trade and other barriers, the world has been transformed into a global village.

Consequently, SMEs in developing countries are struggling to survive under intense competitive environments both domestic and international. In developing countries like Nigeria, there is an urgent need to provide the required enabling environment for the development of SMEs, so that they could adequately play the role expected of them in economic transformation, Such role includes mobilization of domestic savings for investment, appreciable contribution to gross domestic product, increased harnessing of local raw materials, employment generation, and significant contribution of poverty reduction efforts through sustainable livelihoods and enhancement in personnel income, technological development and export diversification (Smatrakalev, 2006). It is for this reason that an ideal tax policy needs to be adopted in order to ensure economic growth and proper utilization of resources. However this is not the case because taxes which are levied for regulating the investment behavior of the households and not for suffocating any entrepreneur initiative seem to be a major constraint to the development of the SMEs they are out to cater for.

Olorunshola (2003), the concept of SMEs is relative and dynamic. The characteristics of SMEs are uncertainty, innovation and evolution. A firm understanding of SMEs world required a good knowledge of its features. In Nigeria SMEs are usually small in size and lack large organizational structure and management culture while the urban SMEs are more structural, the rural ones are less structured. This represents one of the most important characteristic of SMEs in Nigeria. SMEs are in most cases a one man business or partnerships enterprise, although they many be registered as limited liability company, (Udechukay, 2003). Olurunshola (2003) affirmed that this ownership style has led small and main enterprise to have a simple management structure and make it easiest to manage than that of large firms, and few numbers of staff and in some cases low level of education by some owners of SMEs. SMEs almost shave the same characteristic with a sole proprietorship in that, there is no legal personality between the SMEs and their owners, which means that the life span of SMEs depends on the life of the owners; when the owner dies, if not properly taken care by the estate the business will die with the owner(s) Another feature of the SMEs sector in some countries is its heterogeneous nature, ranging from retail outlets to hugely paid professionals and substantially manufactured organisation small and medium enterprise are also likely to vary in organizational form, from sole proprietorship (one man business), scale corporations (public or private), professionals and partnerships.

Furthermore, the process of production in SMEs setting are Labour intensive and they always serve as supplier to the large manufacturing firms by depending on raw materials sourced locally (Hanefah, Ariff and Kasipfflai, 2002). Just like a one man business SMEs also required low start up capital than large companies (Akinsulise, 2010). Also, the 
decision of manager have higher tendency to be subjective as they are controlled by the same person and the employees employer relationship found in most SMEs is predominantly informal.

In addition, the contribution SMEs usually make to tax revenue is lower than its contributions to output and employment (International Tax Dialogue, 2007), that not with standing SMEs have not become competitive enough to increase their shave of output even though they form three fifths of the number of manufacturing industries which are solely rely upon by large manufacturing companies for their supplies (products) (Hanafah et al. 2003).

Depending on the country's international standing at any point in time and the economic policies adopted by government, the importance of the various source of revenue varies from time to time. Nigeria has mixed economy i.e., government undertakes commercial investment alongside the private sector with social oriented economic policies, government undertakes greater commercial investment. Though taxation may not be the most important source of revenues to government in term of the magnitude of revenue derivable from taxation however, taxation is the most important source of revenue to the government, from the point of view of certainty, and consistency of taxation. In a social oriented economy, only a small percentage of revenue may be derived from taxation while in a capitalist oriented economy, a grater percentage of government revenue, is derivable from taxation (Osita, 2004). According to Eftekhari (2009), taxation has always been an issue for the government and taxpayer alike from the early years of civilization. The issue of taxation has generated a lot of controversy and several political conflicts over time. According to its importance, several economic thrones have been proposed to run an effective system. Osita, (2004) sees taxation as a compulsory levy by government through its various agencies on the income, capital or consumption of its subjects. Tax is basically of three structures proportional, progressive and regressive. Proportional tax is define as a type of tax in which tax payer is levy an amount in proportional to his earned, progressive tax levies are higher rate on higher income earners, while the regressive tax is the one that charges higher rate to person receiving lower income. Tax is classified into two broad categories as direct and indirect tax.

Multiple taxations in relation to a company or individual is a situation where the same profit or income respectively which is liable for tax in Nigeria has been subjected to tax by another tax authority in Nigeria or another country outside Nigeria (Osita, 2004). In such situations relief is usually granted to that tax payer for the earlier tax paid or to which he may be liable. Specific arrangements are made with a view to preventing such multiple taxes or to provide relief as is appropriate in the circumstance.

\section{Challenges of SMEs}

There are a lot of problems that bedevil SMEs and stunt their growth. Although there are some problems peculiar to a particular country, the challenges faced by SMEs in different countries and geopolitical divisions are basically the same. For instance, a survey of Turkish SMEs by Organization for Economic Co-operation and Development (OECD) in 2004 showed that they were suffering the consequences of policy inconsistency, poor access to finance, insufficient know-how and low level of technology, and so many others. The same problems were also registered by other authors concerning other regions like the Philippines, Malaysia and other European states and of course in Sub-Saharan Africa-Nigeria inclusive as shown by different authors on the issue. Uzor (2004) believes that the constraints faced by SMEs in developing countries are not only accentuated with ineffective policy design, but also by market failures in the region. Their lack information technology and knowledge of automation is gradually being reduced given that they serve as contractors for larger firms particularly the foreign manufacturing firms. A major difficulty faced by SMEs is that of lack of access to short and long term capital. Publication of the Weekly Trust of Saturday, January 22, 2011 recognizes the fact that collateral based financing has become increasingly difficult for SMEs, whether as existing businesses, in their expansion states or as startups hence more SMEs are resorting to viability lending in which case they obtain loans based on the viability of the business and health of cash flow, Banks are usually reluctant to lend to SMEs and this is because of problems such as the SMEs' inability to meet the bank's lending requirements, promoters' low education, management and entrepreneurial skills and poor and unreliable financial records which makes financial review difficult (Aderemi, 2003). There is also the problem of unsound accounting system and lack of full financial disclosure (Jan, n.d.). Areetey\& Ahene, (2004) buttressed this assertion by listing lack of access to land, utility installation and services, and import procedures as constraints to SME growth Summarily, these problems make SMEs a "high-risk" venture. The above named reasons are in and of themselves problems that impede SME growth because not only do they become obstacles in accessing financing, they are capable of hindering growth on their own. Moreso, in Nigeria, the problems faced by SMEs as posited by Oboh (2002); Okpara (2000); Wale-Awe (2000) and Chu, Kara \& Benzing, (2008) include astronomically high operating costs; lack of transparency and corruption; and the lack of interest and lasting support for 
the SMEs sector by government authorities, dilapidated state of Infrastructural facilities, unreliable employees and Weak economy, unsafe location, undependable electricity supply are common phenomenon.

\section{Empirical Issues}

\subsection{Tax Policy and the Growth of SMEs}

According to Tomlin (2008), economists argue that the resources smaller companies direct towards tax compliance are resources that could otherwise be used for reinvestment, facilitating future growth. Hence, there is a belief that taxes and a complex tax system put disproportionate pressure on smaller businesses. Small taxpayers under the regular system of taxation are discriminated against, since the compliance requirements, cost of compliance and tax rate are the same for both small and large enterprises. Reducing the compliance costs and tax rate increases the small enterprises profit margin. It also increases the Government's tax revenue, since the simplified provisions for a micro enterprise historically reduce the size of the shadow economy and the number of non complying registered taxpayers (Vasak, 2008). Furthermore, SMEs usually have to operate in an overbearing regulatory environment with the plethora of regulatory agencies, multiple taxes, cumbersome importation procedure and high port charges that constantly exert serious burden on their operations. Many SMEs have to deal with myriad of agencies at great cost as stated earlier they are heterogeneous and these differences in size and structure may in turn carry differing obligations for record-keeping that affect the costs to the enterprises of complying with (and to the revenue authorities of administering) alternative possible tax obligations. Public corporations, for example, commonly have stronger accounting requirements than do sole proprietorships, and enterprises with employees may be subject to the full panoply of requirements associated with withholding labour income taxes and social contributions (International Tax Dialogue 2007).

An overly complex regulatory system and tax regime or one opaque in its administration and enforcement makes tax compliance unduly burdensome and often have a distortion effect on the development of SMEs as they are tempted to morph into forms that offer a lower tax burden or no tax burden at all (Masato, 2009) and this results in a tax system that imposes high expenses on the society. A poorly executed tax system also leads to low efficiency, high collection charges, waste of time for taxpayers and the staff, and the low amounts of received taxes and the deviation of optimum allocation of resources (Farzbod, 2000). Existing empirical evidence clearly indicates that small and medium sized businesses are affected disproportionately by these costs: when scaled by sales or assets, the compliance costs of SMEs are higher than for large businesses (Weichenrieder, 2007), Among the factors militating against SME tax compliance with are: high tax rates, Low efficiency, high collection charges, waste of time for taxpayers and the staff, and the low amounts of received taxes and the deviation of optimum allocation of resources (Farzbod, 2000). Others according to Yaobin, (2007) are double taxation, no professional tax consultancy, weak tax planning, high taxation cost.

\subsection{Policy Measures that will Encourage SMEs Growth}

Although there is certain policy measures geared towards SME growth in Nigeria, the support needs to be increased, standardized and systematic. Iwuji (2003) believes that it is the role of the government to provide and enabling environment and social services that support businesses and persons. This means enhancing the investment climate in Nigeria for increased economic growth and subsequent tax contribution from all citizens which is necessary because a good number of SMEs operate in the informal economy due to the fact that they deem the tax environment within which they operate unfavorable. These SMEs constitute untapped revenue potential and an even playing field in many countries (International Tax Dialogue, 2007) as such they need to be captured by the tax net. The legislation is a necessary regulator for protection of the business environment and security of the economic agents, for establishment of the necessary social security regulations but at the same time it hampers the business with additional expenditures and administrative obstacles, which place in different positions the SME. The big companies have more choices possibilities. They can either share part of the staff or hire people to deal only with studying the legal requirements and complying with the new regulations, or contract some personal service firm (like E\&Y, Deloitte and Touché, Price Waterhouse etc) to deal with their ax compliance, planning etc. For SME this is a great expense out of their abilities (Smatrakalev, 2006). Shahroodi, (2010) believes that for a tax system to be efficient the tax policy needs to be designed such that the tax rates are appropriate and rational, the exemptions are lower in amount, the tax collection organization are more efficient, the tax burden of the indigent people should be lighter and the fight against corruption and tax evasion should be much more intense. Tax policies can be designed in such a way that they do not only directly affect SMEs but also indirectly push for 
their growth for example the practice in China where tax policy has been designed to encourage SME financing by granting exemptions from business tax for financial corporations that provide guarantee for loans to SMEs and granting tax deductions to market entities and venture capitalists that invest in high- tech SMEs the tune of $70 \%$ of the investment value. Another way is by designing tax policies that encourage human capital training. (Yaobin, 2007) declared that special tax regimes for SMEs may he appropriate policy instruments for minimizing the cost of collection, It is important to note that the awareness of the dangers of inadequate attention to the taxation of SMEs has grown. It can lead, for example, to distortions of competition as a result of uneven tax enforcement, with incentives created to limit growth and to avoid tax through artificial splitting of enterprises. Not least, voluntary compliance by larger enterprises themselves, and by wage earners, may be undermined by the (correct) perception that their smaller counterparts, or better-off neighbours, are getting away with poorer compliance. (International Tax Dialogue, 2007) Hence government intervention will help maintain balance while helping countries exploit the social benefits from greater competition and entrepreneurship. Furthermore, policy incentives such as tax rebate for SMEs that put effort on local sourcing of raw materials, serious in adding value to commodities for exports and other business ethics, should be employed by government. Similarly, government could increase funding for the development of the sub-sector through direct budgetary allocations and enhance private sector investment opportunities that will focus on specific areas of capacity enhancement. And also tax law should be simplified continuously, mainly for three reasons, namely to lower both compliance costs and administrative costs, to reduce uncertainty faced by taxpayers; and to improve the levels of voluntary compliance (Kasipilai, 2005). Pro-business (and Pro-SME) Tax regimes and enforcement should be simple, consistent and predictable.

\section{Theoretical Framework}

\subsection{Theory of Business Growth}

Various authors have postulated theories on business growth. The oldest and the most used theory according to Elhiraika and Nkurunziza (2006) is Gibrat's law of proportionate effect LPE; (1931). Here, Gibrat stipulates that the rate of growth of a firm is independent of its initial size. By implication it would mean that large firms are preferable in context of private sector development given that they create more employment then small firms. Conversely, Jovanovich (1982) states in his learning model that younger firms learn over time, which helps them improve their performance as they accumulate market knowledge. According to this model, young firms grow faster than old ones. More over, give that younger firms are usually smaller than older ones (businesses) for the reasons discuss earlier; Jovanovic deduces that small firms grow faster than large ones. This is a convergence process where small firms will eventually become as large as any other longer firm in the some sector as time goes by.

Church and Lewis (1983) as cited in Olawale \& Garire (2010) on the other hand claim that as a new small firm start and develops, it moves through some growth stages, such with its own distractive characteristics. He also identified the stages of growth as; existence, survival, success, take off and resource maturity. In each stage of development as different set of factors is critical to the firm's survival and success the Churchill Lewis model gives an insight into the dynamics of SMEs growth including the distinguishing characteristics, problems and requirement of growing SMEs and explains business growth process amongst SMEs, The precise moment in time in which a start up venture becomes a new business has not yet been theoretically determined. However the ideal of business survival could be equated with a firm that has fully completed the transaction to stage - two organisation in the five stage of small business growth.

\section{Research Methodology}

\subsection{Research Design}

Since this study involves the collection of views, perspectives or opinions of respondents regarding a particular issue, the study employed a survey research method which involves questionnaire, personal interview with respondents and perusal of past records and publications. This choice was made due to the fact that the survey method is effective when it comes to getting opinions, attitudes and descriptions as well as getting cause and effect relationship. 


\subsection{Population of the Study}

This refers to the entire number of the members or elements in which the researchers are interested. In other words, it implies a set of all possible causes of interest in a given research activity. Thus, the population of the study is ninety one (91) staff of West African Ceramics Limited, Ajaokuta, Kogi State.

\subsection{Sample Size and Sampling Technique}

Sample refers to the selected members of the entire population for use in the study. It is a sub group of observation from a large population in order to make inferences about the characteristics of the large population. Since it would not be convenient for the researchers to study the entire population, we derived our sample size statically by using Yaro Yamani (Abdullahi, 2012) as follow:

$$
\begin{array}{ll}
\mathrm{N}=\frac{\mathrm{N}}{1+\mathrm{n}(\mathrm{e})^{2}} & \\
\text { Where } & \mathrm{n}=\text { Sample size } \\
& \mathrm{N}=\text { Population } \\
\mathrm{e} & =\text { Margin of error }(0.05)
\end{array}
$$

Thus, the sample size is:

$$
\begin{aligned}
& \mathrm{n}=\frac{19}{1+91+(0.05)^{2}} \\
& \mathrm{n}=\frac{19}{1+91+(0.0025)^{2}} \\
& \mathrm{n}=74.1344
\end{aligned}
$$

The sample size consists of ninety one (91) staff of West African Ceramics Limited, Ajaokuta, Kogi State. Total 74 questionnaires were distributed out of which only 62 were properly filed and retuned which represents $84 \%$ return rate. Our analysis was based on the retuned questionnaires.

\section{Method of Data Analysis}

Analysis of data refers to those techniques whereby the investigator extract from data or information that was not apparently there before and which would enable a summary description of the subject studied to be made. The information being referred to here is the information that enabled the study to test the research hypotheses. Also the statistical tool of frequency tables and percentage were used to present and analyze data collected and also tested the research hypotheses with the Analysis of Variance (ANOVA).

Model specification 1 is the analysis of variance (ANOVA) as thus:

$S S B=r \sum\left(X \overline{i j}-\overline{\overline{X)^{2}}}\right.$
$S S B=\sum \sum(X i j-\bar{X})^{2}$

Where: $\quad S S B=$ btw treatment sum of square

$\mathrm{SSW}=$ within treat sum of the square

$\mathrm{x}_{i j}=$ individual observation around their column mean

$\bar{X}=$ grand mean column

$\mathrm{df}=$ degree of freedom $(\mathrm{c}-1)(\mathrm{n}-1)$

$\mathrm{C}=$ number of column

$\mathrm{N}=$ number of observation

$r=$ Number of row

$\Sigma=$ Summation

Level of significance $(0.05$

\section{Data Presentation and Analysis}

The data presented here are those collected from the field survey on the appraisal of the effect of multiple taxations on SMEs in Nigeria. The data were collected mainly from West African Ceramics Limited, Ajaokuta, Kogi State. This will be 
geared towards testing the research hypotheses leading to drawing conclusions, recommendations and suggestions.

Table 4.1: Does your company pay tax

\begin{tabular}{|l|l|c|c|}
\hline \multicolumn{2}{|l|}{ Responses } & Frequency & Percentage \\
\hline a & All the time & 32 & $52 \%$ \\
\hline B & Most of the time & 19 & $31 \%$ \\
\hline C & Less of the time & 10 & $16 \%$ \\
\hline D & Not at all & 1 & $2 \%$ \\
\hline \multicolumn{2}{|c|}{ Total } & $\mathbf{6 2}$ & $100 \%$ \\
\hline
\end{tabular}

Source: Field Survey, 2012.

From table 4.1above, 32 respondents representing $52 \%$ of the total sample size say their company pays tax all the time. 19 respondent representing 31\% say most of the time, 10 respondents representing $16 \%$ say less of the time while only 1 of the respondents representing $2 \%$ of the sample size say not at all. From the score, we deduced that West African Ceramics Limited, Ajaokuta, Kogi State pay tax all the time given the amount of respondents that stood for it.

Table 4.2: How many agencies do you pay taxes to?

\begin{tabular}{|l|l|c|c|}
\hline \multicolumn{2}{|l|}{ Responses } & Frequency & Percentage \\
\hline A & Above three & 14 & $22.6 \%$ \\
\hline B & Not less than three & 27 & $43.5 \%$ \\
\hline C & Above two & 13 & $21 \%$ \\
\hline D & Not less than two & 8 & $12.9 \%$ \\
\hline \multicolumn{2}{|l|}{ Total } & 62 & $100 \%$ \\
\hline
\end{tabular}

Source: Field Survey, 2012.

The table above shows the response rate of how many agencies collects taxes, 14 respondents representing $22.6 \%$ of the sample size say above three, 27 respondents representing $43.5 \%$ say not less than three, 13 respondents representing $21 \%$ say above two, 8 respondents representing $12.9 \%$ say not les than two, From the score, we deduced that at least not less than three agencies collect taxes from small and medium scale enterprises in Nigeria.

Table 4.3: Multiple Taxations Affects the Growth and Survival of SMEs Negatively in Nigeria

\begin{tabular}{|l|l|c|c|}
\hline \multicolumn{2}{|l|}{ Responses } & Frequency & Percentage \\
\hline A & Strongly agree & 16 & $25.8 \%$ \\
\hline B & Agree & 39 & $63 \%$ \\
\hline C & Disagree & 7 & $11.2 \%$ \\
\hline D & Strongly disagree & 0 & $0 \%$ \\
\hline \multicolumn{2}{|l|}{ Total } & 62 & $100 \%$ \\
\hline
\end{tabular}

Source: Field Survey, 2012.

The score on table 4.3 above revealed that multiple taxations affect the growth and survival of SMEs in Nigeria. This is based on the opinion of respondents, at least 26 of them representing $25.8 \%$ strongly agree, 39 of the respondents representing $63 \%$ also agree while only 7 respondent representing $11.2 \%$ disagree about the statement. Meanwhile, no respondent strongly disagree on the statement. 
Table 4.4: Tax Collectors Consider Size of Business

\begin{tabular}{|l|l|c|c|}
\hline \multicolumn{2}{|l|}{ Responses } & Frequency & Percentage \\
\hline A & Strongly agree & 3 & $4.8 \%$ \\
\hline B & Agree & 7 & $11.2 \%$ \\
\hline C & Disagree & 39 & $63 \%$ \\
\hline D & Strongly disagree & 13 & $21 \%$ \\
\hline \multicolumn{2}{|l|}{ Total } & $\mathbf{6 2}$ & $100 \%$ \\
\hline
\end{tabular}

Source: Field Survey, 2012.

From the result on table 4.4 above, 3 respondents representing $4.8 \%$ of the total sample size strongly agree that tax collector considers the size of business for collecting taxes. 7 respondents representing $11.2 \%$ also agree but, 39 respondents representing $63 \%$ disagree that tax collectors considers the size of business for collecting taxes while 13 respondents representing $21 \%$ strongly disagree. From the score, we deduced that tax collectors do not really look at the sizes of business for tax collection.

Table 4.5: A Relationship between SMEs Sizes and Ability to Pay Taxes

\begin{tabular}{|l|c|c|}
\hline Responses & Frequency & Percentage \\
\hline Strongly agree & 16 & $25.8 \%$ \\
\hline Agree & 25 & $40.3 \%$ \\
\hline Disagree & 17 & $27.4 \%$ \\
\hline Strongly disagree & 4 & $6.5 \%$ \\
\hline Total & $\mathbf{6 2}$ & $\mathbf{1 0 0 \%}$ \\
\hline
\end{tabular}

Source: Field Survey, 2012.

From table 4.5 above, 16 respondents representing $25.8 \%$ strongly agree that there is a relationship between SMEs sizes and their ability to pay taxes. 25 respondents representing $40.35 \%$ followed by agreeing to it while, 17 respondents representing $27.4 \%$ disagree and 4 respondents representing 6.5\% strongly disagree the relationship between the sizes of SMEs and their ability to pay. From the result; we deduced that the ability of SMEs is to pay all taxes depends on their sizes, volume of business and level of revenue generation.

\section{Test of Hypotheses}

This section involves the test of the research hypotheses using the analysis of variance (ANOVA). The test is based on the data collected from the field survey on the study. The data is drawn from table 4.1, 2.4, 4.3 for hypothesis 1: and 4.4, 4.5 for hypothesis 2; respectively.

\subsection{Test of Hypothesis One}

Table 4.6: Sample Data 1

\begin{tabular}{|l|l|l|l|l|}
\hline CODE & A & B & C & D \\
\hline Table 4.1 & 32 & 19 & 10 & 1 \\
\hline 4.2 & 14 & 27 & 13 & 8 \\
\hline 4.3 & 16 & 39 & 7 & 0 \\
\hline$x$ & 20.7 & 28.3 & 10 & 3 \\
\hline$x$ & 15.5 & - & - & - \\
\hline
\end{tabular}

Source: Adopted from questionnaire, 2013 
Table 4.7 ANOVA Table

Source: Sample data 1 above, 2013

\begin{tabular}{|l|l|l|l|l|}
\hline Source & SS & Df & MS & F $_{\text {CAL }}$ \\
\hline Between treatment & 1132.14 & $\mathrm{C}-1=4-1=3$ & 377.38 & \\
\hline Within treatment & 416.34 & $\mathrm{~N}-\mathrm{C}=12-4=8$ & 52.0425 & \\
\hline Total & & & & 7.3 \\
\hline
\end{tabular}

\subsubsection{Decision Rule:}

$\mathrm{F}_{\mathrm{tab}}=\mathrm{df}$ under level of significance

$F(V 1, V 2)$ under $5 \%, F(3,5)$ under 0.05 , Standard or critical table value $=4.07$

Compare Fcal a Ftab, 7.3 a $4.07, \quad 7.3>4.07$

Since the calculated $F$ is greater than the critical table value of $F$ which is 4.07 , that is, $7.3>4.07$, we reject the null hypothesis and therefore accept the alternative hypothesis at 0.05 level of significance. This means that the relationship between multiple taxation and SMEs survival is significant. Hence, the continuous extortion of monies from SMEs is capable of crippling the survival and growth of SMEs in Nigeria.

\subsection{Test of hypothesis two:}

Table 4.8: Sample Data 2

\begin{tabular}{|c|c|c|c|c|}
\hline CODE & A & B & C & D \\
\hline Table 4.1 & 3 & 7 & 39 & 13 \\
\hline 4.2 & 13 & 27 & 17 & 5 \\
\hline 4.3 & 16 & 25 & 17 & 4 \\
\hline$x$ & 10.7 & 19.7 & 24.3 & 7.3 \\
\hline$x$ & 15.5 & - & - & - \\
\hline
\end{tabular}

Source: Adopted from questionnaire, 2013

Table 4.9: Test of ANOVA table 1.

\begin{tabular}{|l|l|l|l|l|}
\hline Source & SS & Df & MS & F $_{\text {CAL }}$ \\
\hline Between treatment & 568.08 & $\mathrm{C}-1=4-1=3$ & 189.36 & \\
\hline Within treatment & 721.75 & $\mathrm{~N}-\mathrm{C}=12-4=8$ & 90.21878 & \\
\hline Total & & & & $\mathbf{2 . 1}$ \\
\hline
\end{tabular}

Source: Sample data 2 above, 2013

\subsubsection{Decision Rule:}

$\mathrm{F}_{\text {tab }}=\mathrm{df}$ under level of significance

$\mathrm{F}(\mathrm{V} 1, \mathrm{~V} 2)$ under $5 \%, \quad \mathrm{~F}(3,5) \backslash$ under 0.05 , Standard or critical table value $=4.07$

Compare $F_{\text {cal }}$ a $F_{\text {tab, }}$ a $4.07, \quad 2.1<4.07$

From the ANOVA test statistics above, $F_{c a l}$ is lesser than $F$ tab. That is, $2.1<4.07$. We therefore accept the null hypothesis $(\mathrm{Ho})$ and therefore reject the alternative hypothesis $(\mathrm{Hi})$ at 0.05 level of significance. The implication of this decision is that the relationship between the size of SMEs and ability to pay taxes is not significant. This means that despite the continuous taxing of SMEs by tax agencies, SMEs continued to survive irrespective of the revenue generated by the SMES. 


\section{Discussions of Findings}

Result from the field survey revealed almost all the SMEs in Nigeria pay taxes to government all the time. As revealed by table 4.2, not less than (3) three agencies collect taxes from SMEs in Nigeria. This means that all the tiers of government have their own form of taxes they collected from SMEs. We also have some cases of community levy, youth levy and union or association levy that are also involve in tax collection in Nigeria. Moreso, we found out that multiple taxation affects SMEs growth and survival negatively. This was made obvious by the number of respondents that agreed on the view.

Findings from the field revealed that tax collectors do not consider the size of a particular business in tax collection. Also, taxes are collected in relation to the profit made by the SMEs. As revealed by table 4.6, the ability of SMEs to pay taxes largely depends on their sizes and volume of business, Respondents agreed that there is a relationship between the two variables, that is, SMEs size and ability to pay taxes.

From the test statistics, we deduced that there is a significant relationship between multiple taxation and SMEs survival. Hence, government should discontinue the excessive taxes they collect from the SMEs so they can continue to exist as an entity. The test also revealed no relationship between SMEs sizes and their ability to pay their taxes.

\section{Conclusions}

The study appraises the effect of multiple taxation on SMEs in Nigeria with a study of West African Ceramics Limited, Ajaokuta, Kogi State. From all literatures reviewed, the researchers deduced that the development and operation of SMEs has economic impact on the nation. The researchers established relationships between SMEs' sizes and their ability to pay taxes, multiple taxations and SMEs survival. The researchers therefore conclude that multiple taxations affect the survival and growth of SMEs in Nigeria.

\section{Recommendations}

The research recommended as follows:

1. Tax collection should be defined with respect to which government should collect certain taxes from SMEs. This will avoid the three tiers of government collecting taxes from the same particular organization. Government should also put a policy in place to avoid illegal taxes, such as community levy, boys or youth levy and as well as association or union levy.

2. Taxes should he collected in relation to the sizes and profit of SMEs considering all other factors that can constrain the progress of such SMEs as there is a relationship between SMEs sizes and their ability to pay taxes.

\section{References}

Abdullai, U. (2012). "An Assessment of the Role of Marketing in Nigerian Banking Sector". Unpublished MSc Seminar Paper Presented to the Department of Business Administration, Kogi State University, Anyigha.

Aanu, S.O. \& Ojochogwu (2012), Relationship between Tax Policy, Growth of SMEs and the Nigeria Economy.

Adefila, J.J. (2008). Research Methodology in Behavioural Sciences. Kaduna: Apani Publication.

Ariyo, D. (2005). Small Firms are the Backbone of the Nigeria Economy. Retrieved from http:Jlw ww.africaeconomicanalysis.orglarticle/ genl smallhtm.html

Aryeefey, E. \& Ahene, A. (2004). Changing Regulatory Environment for Small Medium Size Enterprises and their Performance in Ghana. CRC Working

Paper No.30594). Centre on Regulation and Competition (CRC).Retrieved from http:/lageconsearch.umn.edulbitstream/30594/ 1!Cr05013.pdf.

Asika, N. (2006). Research Methodology in the Behavioural Sciences. Lagos: Longman Publishers,

Beck, T. Demirguc - Kunt, A., \& Levine, R. (2005). SMEs, Growth, and Poverty: Cross country evidence. NBER Working Paper 11224, National Bureau of Economic Research. Retrieved from http://w ww.nber:orgipapers/ w11224.pdf

Chu, H.M., Kara, 0. \& Benzing, C. (2008). "An Empirical Study of Nigerian Entrepreneurs: Success, Motivations, Problems and Stress". International Journal of Business Research, 8(2), 102-106.

Eftekhari (2009). Tax Policy and the growth of SMEs: implication for the Nigerian. http:Ilwww.iiorg... 1166. 
Elhiraika, A., \& Nkuriziza, J. (2006), "Facilitating firm entry, growth arid survival with special attention to SMEs", Economic Commission for Africa, Work in Progress ATPC No.46.

Farzbod, J. (2000). "Investigation of the effective factors in the tax efficiency". Unpublished Master's Thesis, Government Management Training Center, Tehran.

Gabay, B.K.G., Romotin, Jr. R.M., \& Uy, E.A.M. (n.d). Economics: Its Concepts and Principles. http://www.slideshare.net/gar deviconceptsoftaxation.

Hanefah, M., Ariff, M. \& Kasipfflai, J. (2002). "Compliance Costs of Small and Medium Enterprises". Journal of Australian Taxation.

Holban, 0.L. (2007). "The Taxation of Small and Medium Sized Enterprise - a hindering factor influencing the European economic growth". Doctoral Dissertation, Alexandry Loan Cuza university of Lasi and Academy of Economics Studies from Bucharest Romania.

International Tax Dialogue (2007). "Taxation of SMEs". Background Paper for the International Tax Dialogue Conference, Bueons Aires. Iwuji, G.I. (2003) Creating awareness on tax matters for small and medium units. (PowerPoint Slide). www.doostoc.com Kasipillai, J. (2005). A Comprehensive Guide to Malaysian Taxation: Current Year Assessment. Kuala Lumpur: McGraw-Hill

Masafo, A. (2009). "Globalization of Production and Competitiveness of Small and Medium Size Enterprises in Asia and Pacific: Trend and Prospects". Publication of United Nation Economic and Social Commission 'for Asia and the Pacific (ESCAP). Studies in Trade and Investment Series Paper, pg.1-31.

Nwana, O.C. (1981), Introduction to Educational Research for Student - Teachers. Heinemann Education Publisher.

Oboh, G.A.T. (2000). "Banks Participation in the Promotion' of SMEs". Being a Paper Presented at the 6th Follows and Associate.

Okpara, F.O. (2000), Entrepreneurship (Tax and Cases). Enugu Nigeria Precision,

Olawale, F., \& Garvwe, 0. (2010). "Obstacles to the growth of New SMEs in South Africa: A Principal Component Analysis Approach". African Journal of Business Management, 4(5), 729-738.

Olorunshola, J.A. (2003). Problems and Prospects of SMEs in Nigeria. Paper Presented at CBN Seminar on Small and Medium Industries Equity Investment Scheme (SMIEIS). www.cenbank.orglout!publications/guidelines/ dfd/2004/smieris.pdf

Oloth, B. (2011, January 22). "How to qualify for SME Finance". Weekly Trust, Pp.56.

Osita, Aguolu (2004). Taxation and Tax Management in Nigeria. Meridian Association 36 Zik Avenue, Uwani, Enugu.

Panitchparkdi, S. (2006). Statement at the 10th Session of the Commission on Enterprise, Business Facilitation and Development, Geneva, 21 February 2006. www.unctad.org/temp1ates/webfiyers.asp

Shahrodi, S.M.M. (2010). "Investigation of the effective factors in efficiency of tax system". Journal of Accounting and Taxation, 2(3), 4244.

Srnatrakalev, C. (2006). "Tax Policy for SMEs", Paper Delivered at 6th Global Conference on Business and Economics. Gutman Conference Center U.S.A.

Stern, R.E., \& Barbour, P.A. (2005). Designing a small business tax system that enhances growth: Lesson from Africa. www.fias,netnsf

Tomlin, B. (2008). Cleaning Hurdles: Key Reform to Make Small Business More Successful. (Commentary No.264). Toronto, Ontario CD. Howe Institute. www.cdhoweorg/pdf/commentary 264.pdf

Udechukwu, F. N. (2003). Survey of Small and Medium Scale Industries and their potentials in Nigeria. Paper Presented at Central Bank of Nigeria on Small and Medium Scale Industries Equity Investment Scheme (SMIEIS). www.centbank.orgloutlpublicationlguideline /dfdi2004lsmieis.pdf.

Uzor, 0.0. (2004). "Small and Medium Scale Enterprises Chester Development in South — Eastern Region of Nigeria". Institute for World Economics and International Management Paper No.86.

Vasak, S. (2008). Small, Medium and Large Enterprises. USAID Business Climate Reform. www.pdf.usaid.gov/pdf doc/DNADO675.pdf Weichenriedev, A.J. (2007). Survey on the taxation of small and Medium Size Enterprises: Draft Report on Responses to Questionnaire. Organization for Economic Cooperation and Development Website. www.oecd.org/dataoecd! 52/39597756.pdf

Williams, M.S. (2006). "Supporting the Growth of Small and Medium Enterprises". Central Bank of Trinidad and Tobago.

Yoabin, S. (2007, October). "Tax, Small Business, Growth: Effect of Taxation on Investment and Cross-Border Trade". Paper Presented at the ITD Conference on Taxation of SMEs. 